SH 11
. A5
1916
Copy

SH 11
.A5
1916
Copy

SH 11
.A5
1916
Copy

SH 11
.A5
1916
Copy 1

1

1

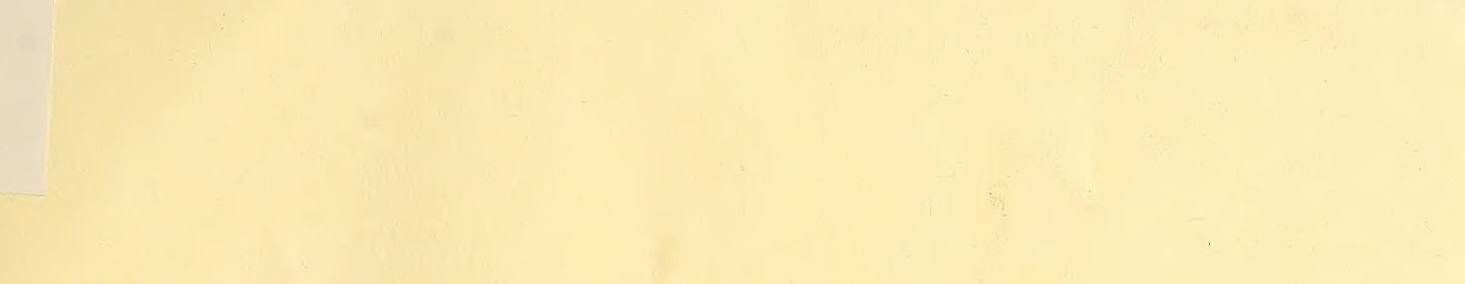

n
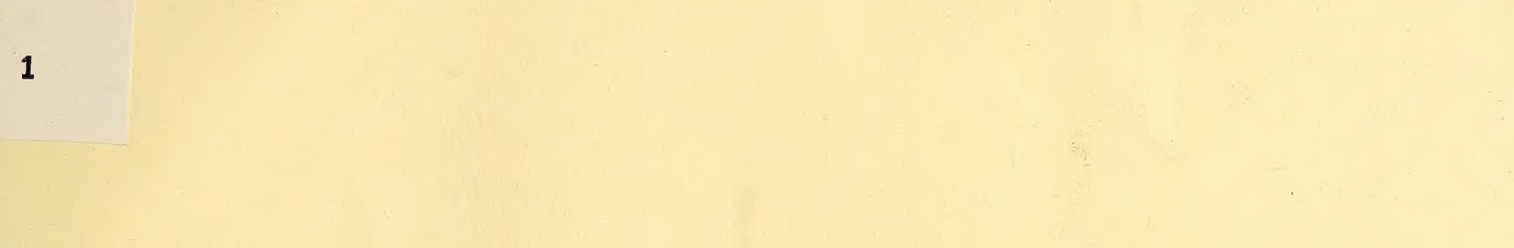



\section{DEPARTMENT OF COIMIMERCE} BUREAU OF FISHERIES

HUGH M. SMITH, Commissioner

INVESTIGATION, EXPERINENTS, AND SURVEYS RELATIVE TO THE AQUATIC RESOURCES OF THE UNITED STATES CONDUCTED BY THE BUREAU OF FISHERIES DURING THE FISCAL YEAR ENDED JUNE 30,1916

\section{CONTENTS}

Sturies of ITarine Fishes

Studies of Marine Fishes . . . . . . 34

Shellfish Investigations . . . . . . . 35

Progress of Diamond-Back Terrapin Culture . . 37

Surveys of Fishing Grounds . . . . . . 38

Oceanographic Studies . . . . . . . 39

Studies of Anadromous Fishes . . . . . 4I

Investigations Relating to Fresh-Water Fishes . 42

Service of the Biological Laboratories . . . . 45

Miscellaneous Investigations . . . . . 48

[Extracted from the Report of the Commissioner of Fisheries to the Secretary of Commerce for the fiscal year ended June 30 , 1916, pages 34-49]

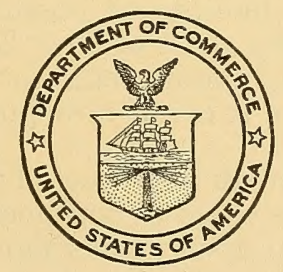

Bureau of Fisheries Document No. 836a

WASHINGTON

GOVERNMENT PRINTING OFFICE

1917 


\section{AQUATIC RESOURCES OF THE UNITED STATES.}

STUDIES OF MARINE FISHES.

Notwithstanding the long existence of great marine fisheries and the common assumption of their inexhaustibility, the development of modern fisheries has been such as to call for the artificial propagation of certain species and to create a demand for knowledge of the life histories, the habits, and the migrations of the important fishes. This knowledge is desired in order that we may determine with what impunity the fishing methods may be continually increased in extent and thoroughness, or what measures of protection may be appropriate, and so that we may properly appraise the value and the possibilities of cultural operations as applied to marine species. The problem must be approached through a complex but systematic plan of study, and final results are not obtainable in a short time. Nevertheless, the continued collecting of fishes at various places and in the different seasons, the persistent application of the methods of modern science to the details of structure that may be characteristic of different localities or ages or seasons or that may be indicative of migrations or other phenomena of life, and the careful consideration of the conditions and results of commercial fisheries will bring us finally to the attainment of a degree of precise knowledge that a few years ago we could not have anticipated.

The investigation of the sea herring, which, as the basis of the herring and sardine industries, is one of the most important fishes of the North Atlantic coast, has been continued in connection with the oceanographic work of the schooner Grampus. The analysis of the data gathered has been pushed as rapidly as possible and it is expected that the results will be ready for publication within a short time.

The most important commercial fish of the South Atlantic and Gulf seaboard is the mullet. Careful studies pursued through temporary services in connection with the Beaufort laboratory have laid a definite and necessary basis for more comprehensive inquiries when it may be possible to carry them out. It is expected that a detailed report of the result of the studies can be published after the conclusion of one more season's work.

An investigation of the habits and possible races of flounders has also been undertaken on the coast of New England, but as the study is only in its incipiency and the investigator has not yet been able to devote to it his entire time it is not now possible to report a definite degree of progress.

For several years the Bureau has directed attention to the condition of the tuna fishery on the coast of southern California, which, with the canning industry based upon it, has shown such marked development in the last few years. The fishery and canning industries are subject to unfortunate vicissitudes because of the irregular appearance of the tuna in the waters accessible by the present methods of fishery. Nothing of a definite nature has been known as to the habits of the tuna, the causes that govern their appearance and disappearance, the parts of the ocean generally frequented by them, or the localities resorted to for purposes of breeding. For nearly two years the Bureau has attempted to gain such information as was 
obtainable through investigations conducted from shore or by the use of small boats. It was realized that the proper method of attack was through investigations extending over a large area of the ocean and conducted through the instrumentality of a seagoing vessel. This was fortunately made possible in February, 1916, when Congress through an urgent deficiency bill provided an appropriation which enabled the Bureau to detail the steamer Albatross for special service in the tuna investigation. The first cruise was promptly begun, and on May 10 the vessel arrived at San Diego after spending three weeks in cruising along the coast of Lower California and several hundred miles farther south and west, as far as Los Coronados Islands. Other cruises followed this one, and the investigation was in progress as the fiscal year closed. From the middle of April to the middle of May there were no tuna along the Lower California peninsula from San Diego to Socorro Island and westward to Guadalupe Island. Two of the best practical tuna fishermen of San Diego accompanied the vessel on this cruise. In the latter part of May tuna were encountered off Lower California near San Geronimo Island, and near the San Benito Islands; none were found on a cruise extending west of San Diego 150 miles. During the month of June tuna were present off San Diego and San Pedro, although they were not taken in commercial quantities, this being attributed to the coldness of the surface water. The investigation has been somewhat hampered by the continued prevalence of rough weather, but will be continued and prosecuted as actively as possible during the next fiscal year.

The importance of a knowledge of the larval development of fishes was cited in the last annual report. Such studies have been continued both at the Woods Hole laboratory and in connection with the investigations in Chesapeake Bay. At the Woods Hole laboratory substantial information was gained regarding 12 species, 6 of which are of direct commercial importance, namely, the tautog, cunner, scup, sea robin, whiting, butterfish, anchovy, menhaden, glut herring, silverside, three-spined stickleback, and four-spined stickleback. For years the Bureau has endeavored to gain information regarding the breeding habits of the menhaden. With the knowledge gathered during the present fiscal year, the Bureau is now in better position to follow up the life history of the menhaden.

Near the close of the fiscal year and in connection with the Chesapeake Bay investigations, additional data were obtained regarding the eggs and larvæ of the anchovy, hog choker, goosefish, and gray trout (squeteague). Experiments with hatching of butterfish were attended with success.

\section{SHELLFISH INVESTIGATIONS.}

The oyster, as the most important food resource of our waters, has continued to command such attention as it was possible for the Bureau to bestow. Owing to the fact that oyster culture, where it is now practiced, has reached a relatively advanced stage of development and, where not practiced, is hindered by peculiar economic conditions, the problems of the industry are comparatively complex and difficult of solution. Until the close of the fiscal year 1916 the Bureau had not been in position to give the continued and effective attention to the oyster that it deserved. Recent action by Congress has to a large extent remedied this deficiency and more effective serv- 
ice to the oyster fishery may be expected in the future. This has been brought about by the establishment of several new positions carrying salaries that will attract and retain competent assistants.

Meantime the Bureau has sought to attack such problems of oyster culture as were adapted to its means and facilities. Encouraging progress has been made in studies of the propagation of oysters, the nutrition of oysters, and the occurrence of phenomena of "greening" and "green gill." In the study of "green gill" the results have been of unusual interest and value. While no method of controlling the "green gill" has been determined, it seems well established that the green color is due to the presence of a particular diatom, one of the minute floating plants that form a large element of the food supply of oysters. This particular species of diatom is known as Navicula ostrearia, and is identical with the form which is abundant in the region of Marennes, France, and which gives to the oysters of that region the peculiar color and flavor which are so highly esteemed. It is not yet ascertained what are the causes of the peculiar abundance of this form in certain years and in certain localities, but when it is known to the public that the occurrence of "green gill" merely means that the oysters have attained a condition that is so highly esteemed in the markets of Europe much should be done to dispel the present prejudice which occasionally causes great financial loss to our planters. Instead of being dreaded or a cause of pecuniary loss, the "green gill" may be welcomed as giving the opportunity to supply a superior article at perhaps a premium in price. These statements do not apply to the oysters which are marked by greening of the entire body owing to the presence of certain mineral salts in the water. This is a distinct condition not easily confused with the well-known "green gill."

The problems of oyster culture on the Pacific coast, where an industry of great possibilities is contending against peculiar natural difficulties, have received recognition, although not as yet in a manner commensurate with the actual needs. Some support has been given to investigations being pursued in Puget Sound, and the progress attained has been such as to justify the Bureau at the close of the fiscal year in arranging to extend a substantially increased measure of financial aid.

The remarkable growth of the blue-crab fishery during recent years has made protective action seem imperative, and the Bureau has been repeatedly importuned for counsel as to the propriety and effectiveness of specific measures proposed and for information regarding the habits and life history of the crab. Since the blue crab is migratory, passing at different stages of its life cycle from the waters of one State into those of another and going from the bays to the ocean and back, the Federal Government is the only agency which can properly and effectively complete the necessary investigations. The result of careful attention to the matter has been to perfect before the close of the year an arrangement under which competent services are secured for attacking the study in a thorough manner. 


\section{PROGRESS OF DIAMOND-BACK TERRAPIN CULTURE.}

The success which has previously been attained in the experiments in terrapin culture has been continued in the past year in even more marked degree. It is timely to summarize some of the more important results at the Beaufort laboratory.

(1) Perhaps the most interesting development of the year is the fact that the three oldest broods of terrapin that were hatched in the experimental pounds and grown in captivity have produced eggs. The two oldest broods, one of which had been winter-fed during the first season while the other had been permitted to hibernate, began laying in 1915 and the eggs hatched successfully. The terrapin of the hatch of 1911 laid eggs in 1916, before the close of the fiscal year. These significant inferences may be made: $(a)$ That terrapin born and reared in confinement develop in a normal way and will reproduce their kind; (b) that the reproductive cycle may be completed in six years, even though the terrapin hibernate as in nature; $(c)$ that by preventing hibernation and forcing growth through the first winter by feeding in a heated house the maturity as well as the growth of the terrapin may be advanced by one year, so that a new generation is started in five years rather than in six.

(2) The adult breeding stock of terrapin has from year to year steadily increased in productivity, and there is ground for belief that the adult breeders have not yet reached the maximum capacity for reproduction. The following figures show the number of young produced by adult breeders during each of the past four years and also the average number per female yielded by the original stock of breeders:

\begin{tabular}{|c|c|c|c|}
\hline & Year. & $\begin{array}{l}\text { Number of } \\
\text { young from } \\
\text { all adult } \\
\text { breeders. }\end{array}$ & $\begin{array}{l}\text { Average } \\
\text { number per } \\
\text { female of } \\
\text { original } \\
\text { breeding } \\
\text { stock. }\end{array}$ \\
\hline $\begin{array}{l}1912 . \\
1913 . \\
1014 . \\
1915 .\end{array}$ & ..... & $\begin{array}{l}1,326 \\
1,506 \\
1,690 \\
2,128\end{array}$ & $\begin{array}{l}12.81 \\
14.52 \\
15.23 \\
21.43\end{array}$ \\
\hline
\end{tabular}

Those terrapin which have been longest in captivity produced in 1915 an average of 21.43 young for each female.

(3) The value of winter feeding during the first season is well established by the increased rate of growth, the shortening of the time required to attain reproductive maturity, and the very low rate of mortality. The death rate has never been so low as during the winter of 1915-16. Among 700 terrapin fed on fresh food the loss was about $6 \frac{1}{2}$ per cent, while among those fed on salted food the loss was about $8 \frac{1}{3}$ per cent. The death rate in hibernating stock was 13 per cent. The cost of food for winter feeding at Beaufort varies from 3 to 15 cents per 1,000 young terrapin per day, according as salt fish, fresh issh, or oysters are used. Assuming 10 cents as an average daily expenditure per 1,000 terrapin, the cost of food for 1 terrapin for a period of 5 months in the first winter would be $1 \frac{1}{2}$ cents. 
(4) The death rate among terrapin after the first season is so small as to be nearly negligible. It is found to be about 1 per cent in the second year, diminishing with age to one-half per cent and less. The principal mortality occurs in the first season, and is then found to be chiefly among the "runts," which should probably be culled out in ordinary practice. While the death rate has been as high as 20 to 25 per cent during the first season, it has now been reduced, partly through improved methods of sanitation, to less than 10 per cent. The losses are remarkably low when it is considered that deaths occur principally when terrapin are very young and before they have become a source of expense, and that the productivity of the terrapin is such that even a loss of 30 per cent at this stage could readily be compensated for by increasing the numbers hatched and saved for rearing. So far as regards disease and death rate the rearing of terrapin is a matter of much less difficulty than the raising of poultry.

(5) The history of our experiments during many years gives strong grounds for belief that domestication of terrapin is accompanied by increasing productivity and diminishing disease and mortality. Our experience indicates the advisability of retaining a select brood stock for a rather indefinite period, instead of adopting new breeders from year to year, as might be done in stock raising. Some of the breeders have been in captivity for about 14 years.

It may be noted that the experiments in terrapin culture have not the nature of small laboratory tests but are carried out upon such a scale as to be comparable to commercial operations. It is possible also to check our results against those obtainable in a large local commercial venture which has adopted methods based upon those followed in the Bureau's work. From this it appears that the various results gained in the Bureau's experimental work are not to be taken as exceptional, but that they are, in a general way, typical of what may be expected in cultural operations conducted according to sound principles and with the exercise of proper care.

There are now about 3,000 terrapins under observation and classified in more than 25 experiments which are being directed to obtain definite answers to practical questions that yet demand attention and justify the continuance of the investigations. Among these are: What is the proper proportion to maintain between males and females, and what are the best conditions for prolificness in eggs and for successful hatching? What are the possibilities of improving rate of growth by selection, and what are the opportunities for promoting economy through proper culling or other methods? These are only some of the practical questions which warrant further investigations.

\section{SURVEYS OF FISHING GROUNDS.}

Some further work has been done in extending the known limits of the blackfish grounds off the coast of North Carolina. The Bureau maintains a buoy on the principal grounds, which is of service to fishermen both in locating this particular ground and as a bearing from which to find other grounds. The fishery is not developed in proportion to the evident possibilities, owing partly to the lack of suitable boats and partly to the unwillingness of local fishermen to engage in operations at any distance from the shore. One or two crews have, however, taken advantage of the opportunities and the 
fishery was regularly followed through the winter and spring of 191516 with results that were very satisfactory to the fishermen and the vessel owners.

The survey of halibut grounds lying off the coasts of Oregon and Washington was continued by the steamer Albatross during the first three months of the fiscal year. The first trip of the Albatross was to grounds off the coast of Washington from Grays Harbor to Flattery Banks, but the abundance of ground and blue sharks rendered the location unpromising for the establishment of a fishery at that time. Two especially favorable halibut bottoms were discovered, one 31 miles west of Grays Harbor and the other 37 miles S. by W. from the Umatilla Lightship.

The second trip covered the same region by lines of sounding intended to determine the possible existence of offshore banks rising from the deep water. One such bank was located as apparently the top of a submerged mountain, rising 6,000 feet from the floor of the ocean. The depth ranged from 525 to over 830 fathoms. The bank is not shoal enough for fishing, but it suggests the possible existence of other banks that might be of greater practical importance. The location of the bank is about 278 miles from Cape Flattery Light, the latter bearing $\mathrm{N} .66^{\circ} \mathrm{E}$.

A third trip covered the region off the Columbia River and south therefrom as far as Cape Meares. Good halibut bottom was found S. $71^{\circ} \mathrm{W}$. of Columbia River Lightship, 17 miles out. South along the 100-fathom curve to Cascade Head good bottom was noted for nearly the entire distance in 110 to 120 fathoms. A patch of suitable bottom was located 22 miles northwest of Cape Meares Light in 94 fathoms. The largest ground discovered by the Albatross on this trip lies between Tillamook Head and Cape Falcon, 28 to 30 miles from the coast. The bottom is of coarse and fine gravel, black sand, and granular shale, and an abundance of life was noted at the surface of the water. Important hydrographic observations were made and reported to the Coast and Geodetic Survey and to the Nary Department. A report of the halibut survey, with charts, will soon be published.

\section{OCEANOGRAPHIC STUDIES.}

If we were interested to know the capacity of certain lands for the support of particular kinds of animals; if we wished to ascertain the causes of the natural movements of such animals; or if we were to determine upon a proper policy of handling our stock in governance of their capture, or in endeavors to increase their numbers by cultural methods, we could not neglect to consider the character of the land in its various parts, its yield in vegetation small and large.

Similar inquiries, roughly speaking, when applied to the ocean constitute the science of oceanography. However it may appear to the eye, the ocean is not one great homogeneous body of water, but is marked by a diversity such as we are familiar with upon the land. Variations in depth, in saltness, in temperature, or in richness of animal and plant life are always encounterable, whether we proceed from the shores to the open sea, from the surface to the bottom, from east to west or north to south, from any one geographic region to another. There are variations from year to year, even from season to season; there exist veritable deserts where abundant fish might 
starve from want of food, contrasted with zones of plenty. There are currents and counter currents and blendings of different waters. In one geographic locality, waters flowing from tropical regions and laden with characteristic animals and plants may overlie waters emanating from arctic domains and carrying their peculiar types of living things. If we do not have knowledge of such conditions, we can not determine whether a condition of extreme paucity of fish life such as was conspicuous on our eastern shores in the summer of 1916 is an indication of exhaustion of the fisheries or is an inevitable consequence of observable oceanographic abnormalities that can not be affected by man's operations; we will not be able to understand what general movements of fishes or variations in local abundance of fishes are attributable to unwise human operations and what are properly to be expected as a reflection of normal phenomena of nature.

Oceanographic studies are not new in this or other countries; and extensive data have been gained by the Bureau at various times during many years, but within the past few years the Bureau has planned for better coordination of such studies as could be conducted within its means. Operations have been pursued intensively in restricted regions, so that a completed exploration might be made and relations established with a degree of definiteness that would make it possible to deduce some practical conclusions.

The investigation of waters off the Atlantic coast, primarily in the Gulf of Maine and southward to the Grand Banks, has been continued in connection with studies of the life history and habits of the herring and other fishes. The schooner Grampus was detailed to this work with an assistant from the office in active charge of the observations, while the investigation was under the fortunate direction of a skilled oceanographer whose services were available to the Bureau. The results gained during preceding years have been made public from time to time and a final report may be expected within a short while.

Near as the Chesapeake Bay is to the center of administration and important as its fisheries are, we have been without systematic and detailed knowledge of the physical and biological features of its waters and of the effect of such conditions upon the constant movements and varying abundance of important fishes. Beginning in October, 1915, the steamer Fish Hawk was detailed to a general investigation of the Chesapeake Bay under the direction of a wellequipped assistant. At intervals of a month or six weeks there have been cruises over the bay, while observations of various sorts were made and material collected for later careful study. The investigation was by no means confined to technically oceanographic subjects, but a number of useful inquiries were embraced in the general scope of work and many valuable services rendered. The existence of resources in hydroids, or "sea moss," the basis of a possible new industry was demonstrated; the spawning habits and the life histories of fishes were studied; experiments were made with the propagation of certain species; crab fishermen were induced to experiment successfully with use of pickled dogfish and shark meat as bait, and a probable use established for a fishery product that had hitherto been wasted. The United States National Museum, upon invitation from this Bureau, also took advantage of an unusual opportunity to add to its natural history collections. The survey must be ex- 
tended into the next fiscal year before it can reach a stage of completion.

Each important vessel, where engaged in other primary investigations, has taken advantage of the opportunities for recording hydrographic observations as far as consistent with the economical prosecution of its immediate objects. Thus data of some value have been reported by the steamer Albatross while pursuing special studies of the western coast and by the steamer Fish Hawk while working off the coast of North Carolina.

\section{STUDIES OF ANADROMOUS FISHES.}

Among the most highly esteemed of our food fishes are those that spend the greater part of their lives in the ocean, but at one stage enter the rivers for the purpose of reproduction. Such are the salmons, the striped bass, the shad, and the sturgeons. Crowding as they do at one particular season into certain restricted channels, namely, the river courses of our coastal slopes, they become the more readily an easy prey to man's pursuit. Unless the greatest foresight and restraint are exercised in the fishery, and the methods of artificial propagation are resorted to, such fishes are certainly doomed to rapid diminution, if not complete disappearance. The absolute abundance of anadromous fishes is too easily overestimated. Take all the shad which even in past times entered our rivers and strew them widely over both land and water of the coastal plain, and their "abundance" would be lost to view; or, as may indeed be done in nature, scatter them over the continental slope beneat $h$ the ocean waters and they become one of the rarer fishes of the sea. There is little reason to wonder that a shad is so seldom taken in the ocean fishery followed off the greater portion of our coast. It would have to be an extraordinary condition, such as abundant food, perhaps, that would bring shad together in a particular region of the sea that would permit an ocean fishery for shad to be carried on. Such, indeed, appears to be the case of certain regions off the northeastern coast where "sea-run shad" become a feature of the local markets. What is the origin of such shad? Are they a distinct race, or are these the shad that were bred in southern rivers? The extent and directions of migration of the fish are questions of vital interest. To what extent are the runs of one river affected by fishing operations in another? In what degree does artificial propagation in one stream yield returns of value to another? These are all kindred questions or aspects of one general problem for each anadromous species.

Notwithstanding the attention which has been devoted to the shad during so many years, the paucity of explicit knowledge is keenly felt. Early in the fiscal year the Bureau instituted a comprehensive investigation of the shad, hoping that the application of newer methods of investigation may afford the key by which the mysteries may be unlocked. Beginning with the St. Johns River in Florida in January, the investigator has worked up the coast, visiting the principal shad streams as nearly as possible at the time when the fish are arriving from the sea. By the close of the fiscal year he had reached New England, where studies were being made both of the native shad of Maine and the sea shad of the waters north of Cape Cod. Many questions have received attention, $71823-17-2$ 
although the primary purposes have been to determine if shad of different rivers or of different brood regions present distinguishable racial differences and to obtain information as to the extent of the coastwise movements of the fish. Many data have been accumulated and many specimens secured, all of which must form the basis of subsequent detailed studies before exact conclusions can be drawn.

Associated with the shad and horring and having similar habits is the glut herring, a species of considerable abundance but one which until recently found only a limited market in the localities in which taken. The past fow years have witnessed a marked increase in value and diminution in numbers. During the past season experiments were made by an assistant in cooperation with fish culturists to ascertain the best methods of handling and hatching the eggs, and the results have indicated that the artificial propagation of the species on a large scale is feasible.

The detailed study of the life history of the salmon of the Sacramento and Columbia Rivers has been continued and the field work is practically concluded. With the study of accumulated data and the preparation of the report during the ensuing fiscal year, it is expected that conclusions will be reached that will guide our fishcultural operations to a stage of greater efficiency. In the direction of these studies the investigator has had not only the benefit of the most expert counsel but the sympathy and suggestions of practical fish culturists.

INVESTIGATIONS RELATING TO FRESH-WATER FISHES.

The field of fresh-water. fish investigations has been too little touched, although the immediate opportunities of domestic fish culture are probably greatest among fresh-water forms. No one assumes that the great complex of streams and abundant lakes and ponds are productive to their maximum capacity, but rarely is due care taken to conserve in practicable ways the conditions in them favorable to the growth and propagation of fish. This phase of the general problem of fish production is not yet adequately realized nor are the principles satisfactorily developed.

That the streams, lakes, and ponds should be stocked and restocked with fish is an ever growing demand which indicates the widespread interest in such fisheries, whether they serve as a means of recreation or as a source of food. The stocking and restocking of waters is, however, not usually the principal desideratum. In specific instances the actual condition to be relieved may be due to an overabundant stock. Just as agriculture has long since passed the stage where increased production is sought primarily through the planting of more seed in a given area, so it is incumbent to give proper attention to promoting a favorable condition for the growth of fish, looking intelligently to the maintenance of suitable condition of physical environment, abundance of food, proper association of species, and a correct proportioning of numbers and variety of fishes to the biological capacity of the water.

The fishery problems of fresh water are undoubtedly simpler than those of the seas, but they are certainly less directly approachable than the problems of agriculture which have met their solutions. It is not surprising, therefore, that, throughout the country in mat- 
ters of fish culture, there is as yet too little serious endeavor to find real causes or to apply appropriate remedies. Year by vear the Bureau is devoting more careful and fitting attention to the problems of fresh-water fisheries, and some of its principal activities in this field may be referred to.

The problem of fish culture, at least as referring to pond fishes, is primarily one of food supply. Our knowledge of the food of fishes is as yet seriously inadequate. The food taken by fishes varies with the species, with size and age of the fish, with the season of the year, and with the abundance of the various kinds of food materials present in different bodies of water. A few observations in one locality or at one season of the year afford no criterion for the conclusions that we may seek to draw for an appraisal of the possibilities of fish production in any body of water, for an understanding of the variations in the sizes attained by a given species of fish in different bodies of water, and for the direction of our efforts to promote an abundent and reasonably constant supply of food under all conditions subject to control.

One of the investigations of the food of fishes that has been pursued comprises an examination of a number of perch taken from each of two lakes in Wisconsin during each week in the year. At the same time collateral studies have been made of the food of many of the important fishes, their habits and interrelations. Some of the results have been submitted for publication, while other reports are in preparation. The accumulation of such data is not of theoretical interest; it is indispensable to a purpose, for it must lead eventually to intelligent conclusions as to the highest possibilitios in rearing fishes and the methods of realizing such possibilities.

At the Fairport station several special fish-food studies are being actively pursued. In connection with the experiments in rearing buffalofishes, examinations are systematically made to determine the food taken at all sizes and all stages. Investigation of the food of all small fishes in the experimental ponds are being conducted in connection with parallel studies of the available foods in the ponds. Systematic studies are being made of the aquatic insect life. Experiments are also being directed at the problem of promoting an abundant growth of food organisms by methods of fertilizing the water or otherwise.

The investigation of the habits and movements of fishes in the Mississippi River with especial reference to the obstruction of the river by the dam at Keokuk has been continued throughout the fiscal year. Only tentative conclusions have as yet been reached, but the progress of the investigation has been such that it may be hoped to present a full report within another year.

Within the year there has been completed a report embodying the results of an carlier investigation of the Rangeley Lakes of Niaine. These have for many years been among the more widely known for their game fishes, and the investigation was undertaken to gain information that might serve not only as a guide to fish-cultural development of these particular waters but as a basis for tho adoption of a proper policy with regard to other lakes. The roport comprises an unusual body of information regarding the habits and relations of many important food and game fishes. 
There is in progress and now drawing to a conclusion an investigation of the habits of the common smelt, a fish which is of no little economic importance, partly as an object of fishery itself and more significantly as a source of food for the larger food and game fishes.

It is generally known that many species of fish are destructive to the larvæ of mosquitoes, but, where public health is involved, it becomes of high importance to know definitely what fish are most effective in mosquito extermination and under what conditions is their efficiency greatest. In many cases, where the usual treatments of waters are impracticable because of expense or other sacrifice involved, it is convenient to rely upon the agency of small fish, provided there can be assurance that the result sought will be fully accomplished. It is possible that in particular cases partial failure to eliminate all mosquito larvæ can be turned into complete success through the introduction of other kinds of fishes that will be adapted to the particular condition of the pond or through measures taken to so change those conditions that the fish will have a better chance to obtain their prey. It is necessary then to study the comparative efficiency of the different species of fish and to ascertain how the efficiency of the more suitable species is affected by the various conditions of depth, vegetation, and débris.

At the beginning of the fiscal year the Bureau issued an economic circular giving an account of the various species of fish that play an important part in mosquito extermination, and at the same time it entered into cooperation with the Bureau of Entomology for a careful investigation directed to the ends just stated. The inquiry will be continued through the next fiscal year.

In addition to its functions in mussel culture, and without hindrance to them, the Fairport station is being utilized effectively in fish-cultural experimental work. Some of these experiments are being conducted with the game fishes that are favorite objects of cultural efforts. The purpose of these experiments is primarily to ascertain the conditions under which the fish may be reared to a market size in greatest numbers.

During the spring of 1915 unusual success was attained in the hatching of the eggs of the buffalofish after artificial fertilization. A number of the fry were placed in a new station pond to be kept under observation. Notwithstanding the raw state of the pond and other unfavorable conditions, more than 25 per cent of the fish, or about 45,000 , were found to have survived when the pond was drawn in the fall, and some had attained a length of over 6 inches. A good many of the fingerlings were liberated and others were retained for further growth. A proportion of loss was experienced during the winter season, but the experiments are still in progress. Not all has been obtained that could be desired, but, as the first attempt at rearing buffalofish in capitivity, the success is such as to recommend the continued experimentation with a form that is well known as a commercial food fish of large size and of diminishing abundance.

Quite interesting results have been attained too with the channel catfish (Ictalurus punctatus), a form that has hitherto baffled all attempts at propagation. Just at the close of the fiscal year the first successful attempt at propagation was in progress, but the further history of the experiment is a matter for a later report. 
The Bureau is continually called upon for advice in the solution of problems confronting those who are either engaging in fish culture as a private venture or who are interested in developing the possibilities of certain public waters. A station such as that at Fairport, where the hatching and rearing of fishes to a size suitable for the table can go hand in hand with systematic scientific observation and experiment, renders a long needed and invaluable service in providing an experience supplemental to that gained in practical fishcultural work.

During the year the Bureau conducted a survey of the Bonneville System of Utah with reference primarily to its fishery resources and incidentally to the problems of fish protection in irrigation ditches. This system comprises Utah Lake and Provo, Beaver, Bear, Logan, and other rivers. Interesting and unexpected discoveries were made of several new species of whitefish that appear to be indigenous to the system, and all of which are good food fish. Utah Lake is famous for its suckers and carp, tons of which are sometimes shipped to eastern markets, some going even to New York. Generally speaking, however, the fish of the Bonneville System are not plentiful cnough to be of great commercial value except locally. With the development of power plants and the growth of agriculture, they are certain to become less numerous, unless due care is taken to conserve the fish supply as far as may be done consistently with the pursuit of other objects of greater economic importance.

\section{SERVICE OF THE BIOLOGICAL LABORATORIES.}

The seaside laboratories, which opened for the summer season just before the close of the last fiscal year, were in active operation until about the middle of September, 1915. Various investigations were pursued chiefly through the employment of the temporary services of specialists in several lines.

The Woods Hole, Mass., laboratory is intended to serve as a nucleus for investigations of more direct reference to the New England and Middle Atlantic fisheries as well as for more technical investigations of general application. In some respects this establishment is better adapted for technical studies than any other laboratory of the Burcau, and it is hoped to improve the facilities for biophysical and biochemical studies that form essential phases of certain fishery investigations. The lack of a permanent scientific staff for this station causes its scientific operations to be confined largely to the summer season, when temporary professional services are most readily available. The principal topics of investigation during the past season may be cited. There have been studies of oysters, elsewhere referred to, which related chiefly to nutrition, greening, and propagation. The studies of nutrition had especial reference to the discovery of methods of fattening that might not be open to the objections properly raised against some of the common practices. The investigation of greening, directed at a condition which has served as a serious blight on oyster culture in certain localities, and of "green gill," an entirely distinct phenomenon, was also associated with this laboratory. Studies of the larval development of fishes have been followed with results narrated elsewhere. 
Other subjects of investigation were the parasites of fishes and the effect of such parasites upon the vitality of the individuals; the effect upon fishes of certain mineral salts which may be present either as a normal constituent of some spring waters or as a consequence of pollution; the metabolism of fishes and oxygen utilization, subjects which have a bearing upon the propagation and rearing of fishes; the bacteriology of fishes; the biology and the utilization of sea mussels; and the possibilities of utilization of other waste fishes. As usual the facilities of the laboratory were extended to a fow independent investigators whose studies were pursued without expense to the Bureau.

The Beaufort, N. C., laboratory is a center for investigations that look to the better development of the fisheries of the South Atlantic coast. Allusion has been made to the study of the mullet and to the survey of fishing grounds which has revealed opportunities for offishore winter operation and contributed to the development of a fishery that is as yet unduly limited. The successful experiments in terrapin culture are also more fully described elsewhere. Special attention is being devoted to the breeding habits of fishes, the larval development of fishes, and, as opportunity offers, to the possibilities of propagation of certain sea fishes which support important fisheries in the South Atlantic States. Interesting observations were made and a report was prepared dealing with the habits of certain species of sinall fish that are denizens of brackish and fresh waters and that are serviceable in the extermination of mosquito larvæ and hence in the maintenance of public health.

Efficient study of the food of fishes and of the movements of fishes, as directed by the search for food, or the aroidance of enemies, demands an exact knowledge of the forms of animal and plant life which may be encountered in the local waters or which may.be found in the stomachs of the fishes. Careful systematic studies of certain groups of animal and plant life have therefore been in progress for some time. During the past fiscal year there was completed for publication a valuable report on the sharks and rays of the Beaufort region; and another comprehensive report dealing with the decapod crustacea, a group that includes the crabs and other forms of most direct economic usefulness, has also bcen completed and submitted for publication. Systematic studies of certain groups of fish parasites have been completed. A report of the alga of the region is nearing completion, while the diatoms and protozoa, among the lowest forms of minute plant and animal life, as well as the higher fishes, are now subjects of investigation.

In the assurance that the development of commercial fisheries will soon demand more strongly the conservation of important shellfish, serious attention is being given to the life history of the quahaug or hard clam and the principal crustacean forms.

The Beaufort laboratory has also been found a favorable place for the prosecution of certain special problems that have not a particular regional significance. At this place there are pursued investigations of the toxicity of certain chemicals to marine borers and of the protection of wood against these disastrous pests, in which studies the Bureau has enjoyed the cooperation of the forest products laboratory of the Forest Service and the sympathetic interest of railway companies and other commercial bodies. 
The enlargement of the island upon which the laboratory is located, in consequence of the deposition of material dredged by the War Department from nearby channels; the recent additions to the building authorized by Congress; and the grading and sodding of large portions of the island have added greatly to the appearance and to the stability of the property. The station would be of much greater practical service to the fishing industries of the coast were it enabled, through the provision of an adequate permanent staff, to carry on more extensive permanent experimental work. Investigations temporarily pursued serve a useful purpose in laying the basis for practical work, but it is usually only through continuous experi mentation that the inevitable difficulties of new practical work are discovered and successfully overcome, as must finally be done to pave the way to substantial benefits. The terrapin experiments offer a concrete example of a businesslike mode of procedure in fishery experiment work, while other opportunities are awaiting with perhaps greater possibilities.

The Key West, Fla., laboratory becomes nearer to realization with the developments of the past fiscal year, during which the Government has assumed title to the site and Congress has provided the necessary additional appropriation for its construction. The preliminary sketch plans were completed and at the close of the year the final plans were in course of preparation. Bids are expected to be sought by advertisement at no distant date. The laboratory site is properly chosen near a base of supplies accessible by water and rail and the seat of important commercial fisheries. Situated as it is, entirely remote from the influence of fresh-water rivers and on the thoroughfare from gulf to ocean, the conditions should be eminently suitable for work with marine forms. It is hoped to employ the most substantial method of construction, not only because the peculiar conditions of the geographic location demand it but because it is regarded as sound business policy to provide against the continued necessity for repairs and unnecessary operating costs.

When this laboratory is in operation and provided with a staff of trained investigators, the service rendered by the Bureau to the fisheries of the Gulf and extreme South Atlantic coasts will be of more palpable benefit. Some of the evident opportunities are to be found in the study of the artificial propagation of the green turtle, the investigation of such useful forms as the spiny lobster and the stone crab, the fostering of the struggling industry of sponge culture, and the study of the important food fishes of the Gulf of Mexico and Straits of Florida.

The Fairport, Iowa, station, having a permanent scientific staff, is in active operation during the entire year. During the summer season its staff is temporarily augmented in order that particular problems arising from the regular investigations at this station or related to the other activities of the Bureau may be attacked by specialists in particular lines of study. As at the marine laboratories, the facilities of the station are extended to approved independent investigators, who, as table occupants, pursue their researches without cost to the Government.

The propagation of mussels, the fish-cultural experiment work, the investigations of the food of fishes, and certain studies of conditions in the Mississippi River, as elsewhere referred to, are among the 
subjects under consideration at Fairport during the year. One of the investigations pursued at this laboratory was of particular interest in establishing the fact that mussels may absorb nutritive substances in solution in the water not only through the alimentary tract but directly through the surface cells. Other studies in progress relate to the propagation of species of mussels not yet susceptible to practical cultural methods, the relations of fishes and mussels in nature, the possibilities of rearing mussels without parasitism, the food of mussels, the copepod parasites of fishes, and the constitution of the blood of fishes.

The equipment of the station in ponds and other facilities for the efficient prosecution of its work has been materially increased during the year. A bulletin descriptive of the equipment and functions of the Fairport station has just been published.

\section{MISCELLANEOUS INVESTIGATIONS.}

The Bureau has taken advantage of an opportunity to utilize the services of a specialist traveling abroad to secure information regarding recent significant developments in foreign pearl fisheries and expects to have a report available within the next year.

The imperative necessity for seeking new sources of potash for use in agricultural and commercial enterprises has led to the sudden development of an industry of kelp harvesting, especially in the region of San Diego, Cal. Simultaneously there arose questions as to the possible effect of the cutting of kelp upon the fisheries. Just before the close of the fiscal year it had been arranged to begin a study of the kelp fields and the method of harvesting with the view of securing definite information as to the relations of fish and shellfish to the kelp groves as they might be affected by the operations of harvesting.

For two or three years the Bureau has been searching for suitable supplies of hydroids, or the "sea moss" of commerce, which had previously been imported from Europe in considerable quantities. The dyed product is used for decorative and millinery purposes, and the importations for the only year for which statisties are available (1909) amounted to more than 300,000 pounds, valued at $\$ 47,558$. In connection with the survey of the Chesapeake Bay, considerable quantities were located at depths of 18 to 30 fathoms, and experiments were made to devise efficient methods of collecting. An experienced manufacturer accompanied the investigator on one of the cruises and pronounced the material of excellent quality. Further observations must be made to determine the seasons when the moss may be found in greatest abundance and highest quality.

One of the most serious handicaps upon the halibut fishery of the northwest coast is the occurrence of "mushy" halibut, which is especially characteristic of certain grounds and which begins to be noted in early summer, increasing in prevalence until the unmarketable fish form so large a proportion of the catch as to compel the abandonment of the fishery or the removal to other and less accessible grounds for the remainder of the season. Through the study of material supplied to a specialist in the employ of the Bureau, it has been ascertained that the "mushy" condition is caused by a minute protozoan parasite which multiplies abundantly and brings about 
a degeneration of the muscle tissue. As soon as it is possible to do so, the Bureau will undertake a more extensive investigation in the field in order to learn the distribution of the parasite, the conditions that bring about its occasional increase in abundance, and any possible method of remedy or control.

The cooperative work with the State Geological and Natural History Survey of Wisconsin in an inquiry into the biological and physicat conditions of life in inclosed waters his been continued. Progress has been made upon the reports of investigations of Lake Champlain and those of the lakes of Washington and Idaho.

In response to a widespread interest in the subject of frog culture, evidenced by the daily receipt of inquiries for information and advice in the matter, there is in preparation a report dealing with the natural history of frogs. Fiold studies are also being conducted.

An interesting test was made in connection with an experiment in rearing fresh-water mussels at the Fairport station. While the commercial mussels are native to rivers and not to still waters, some fishes which had been infected with the glochidia of mussels in the way ordinarily followed in practical operations were subsequently retained in floating crates and others were placed in station ponds. After two seasons of growth it was found possible to cut and finish buttons from the shells of these artificially propagated mussels. The rate of growth was much more rapid than had been expected. It is not assumed that mussels can be reared commercially in such waters, but the experiment is of interest and value as throwing light upon the nature of the results to be expected from the practical operation in public waters.

While the Federal Government exercises no jurisdiction over the pollutions of waters as affecting fisheries, the Bureau can render a very practical service in the investigation of reported cases of pollution where the importance of the strewm and the alleged extent of the damage done is such as to warrant its taking cognizance of the matter. In some instances the reports are found to be without due foundation, while the agencies complained of are exercising all proper care. A report of the actual facts based upon a carelul and unprejudiced examination of conditions serves to allay suspicions and prevent the further existence of dissatisfaction. In other cases the conditions are observed to be as alleged, but abatement is effected through a clear and convincing presentation of the tiucts to the offending parties, coupled with suggestions as to practicid remedies and an appeal for cooperation. Again, there may be encountered those who are carelessly permitting industrial wastes to render a stream uninhabitable for the more desirable fishes and who are not amenable to reasonable suggestions. In such cases the findings of the Bureau can still serve a useful purpose in directing public attention to a wanton abuse and in reintorcing those who m:y be interested to seek relief by process of law. The Bureau has within the year conducted a number of investigations of this kind and the reports have been placed as promptily as possible in the bands of the parties interested. 


LIBRARY OF CONGRESS

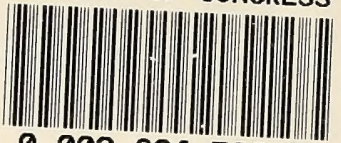

00028245063 
LIBRARY OF CONGRESS

||||||||||||||||||||||||||| |||||||||||

(III|||||||||||||||| 